Original Research

\title{
Reducing Labor Pain Intensity within First Stage Active Phase through Hegu LI 4 Acupressure and Quranic Recital Method
}

\author{
Nurul Azizah, Rafhani Rosyidah, and Hanik Mahfudloh \\ Faculty of Health Science, Universitas Muhammadiyah Sidoarjo, Indonesia
}

\begin{abstract}
Introduction: Labor pain is one of the greatest pains experienced by a woman in their life. The purpose of this study was to examine the effectiveness of acupressure and Quranic recital on labor pain reduction.

Methods: The study design uses quasi-experiment with comparison between pretest and posttest on non-equivalent control group. Samples were as many as 30 laboring mothers in each group, totaling 60 samples who had been chosen through consecutive sampling technique. The labor pain was assessed through the NRS (Numeric Rating Scale) then analyzed univariately with mean and standard deviation, followed by independent T-sample statistical test such as bivariate analysis.
\end{abstract}

Results: The average pain reduction score in the Hegu LI 4 acupressure group was higher than the Quranic recital of Surah Ar-Rahman group. The acupressure group average pain reduction was $3.03 \pm 0.718$ while the Quranic recital group was $2.57 \pm 1.006$. The difference in the average score of independent $\mathrm{T}$-test was significant with the $\mathrm{P}<0.007$ and 95\% C.I. -0.919-( -0.015$)$

Conclusion: Hegu LI 4 acupressure and Quranic recital of Surah Ar-Rahman treatments were promising and may be utilized to reduce labor pain intensity within labor's first stage active phase. Hegu LI 4 acupressure group had a greater reduction in labor pain intensity than the Quranic recital of Surah Ar-Rahman group. This study suggests that Hegu LI 4 can be utilized to reduce labor pain as a non-pharmacological therapy.

\section{ARTICLE HISTORY}

Received: July 7, 2020

Accepted: August 19, 2020

\section{KEYWORDS}

active phase; hegu li 4 acupressure; labor pain intensity; quranic recital

\section{CONTACT}

Nurul Azizah

\nurulazizah@umsida.ac.id

$\equiv$ Faculty of Health Science, Universitas Muhammadiyah

Sidoarjo, Indonesia

Cite this as: Azizah, N., Rosyidah, R., \& Mahfudloh, H. (2020). Reducing Labor Pain Intensity within First Stage Active Phase through Hegu LI 4 Acupressure and Quranic Recital Method. Jurnal Ners, 15(2). 162-166. doi:http://dx.doi.org/10.20473/jn.v15i2.20556

\section{INTRODUCTION}

Pain is a complicated and subjective experience, as it is within the scope of physiological and psychological interaction. Labor pain is the greatest pain experienced by most woman in their lifespan (Yazdkhasti \& Pirak, 2016). Labor pain is the reaction between the uterine muscle contractions which normally happens in labor process. Contraction is intended to give a push to the fetus and opening the birth canal. The resulting effect is that the majority of mothers cannot tolerate this kind of pain, and are mainly affected by stress, fear, tension, and pain (Larasati \& Alatas, 2016). The increasing of mothers' pain perceptiveness results in the mothers' panic level and then begging for a quick labor process, some of them request pain relief medicine, others even request unneeded surgical operations out of fear (Jones et al., 2012).

Heavy labor pain may induce weak uterine contraction, resulting in longer labor process and increasing the risk of hemorrhage (Lozada et al., 2018). In Indonesia, hemorrhages are one of the biggest contributing factors in the mothers' fatality rate aside from preeclampsia/eclampsia and infection (Kemenkes, 2018). Labor pain can be reduced with pharmacological and nonpharmacological methods (Asadi et al., 2015), and wider cervical opening will commonly heighten labor pain (Hawkins, 2010). Pharmacological methods have better effects in treating labor pain, but this treatment can only be done with authorized medical doctors while having more expensive costs (Lozada et al., 2018). The non-pharmacological methods have minimal side effects with cheaper cost or even no 
additional costs while having the same effectiveness in reducing labor pain. Even so, non-pharmacological methods need to be standardized (Gayesi \& Brüggemann, 2010); non-pharmacological approaches, especially acupressure, still need to be researched and expanded further before becoming a standard in addressing labor pain (Robinson et al., 2011).

Mothers' pain experienced in the labor process is unique and natural. The administration and surveillance of labor pain, especially in the first stage active phase is crucial, as it is the determining point of whether the labor process is considered normal or must be ended with interventions because of complications from severe pain (Zhang et al, 2010). The approach of labor pain management increasingly depends on pharmacological methods. Because of side effects on mothers and fetuses, the use of nonpharmacological methods is also increasingly popular (Schlaeger et al., 2017) According to a systematic review by Rahimi et al. (2018), non-pharmacological methods are effective, but the processes are not well defined and standardized.

Acupressure is a non-pharmacological method to relieve pain and included in the Traditional Chinese Medicine (TCM); it is considered as a non-invasive method and based on acupuncture principles (Shahali \& Kashanian, 2010). TCM considers the human body as a united channel to transmit energy (meridian). Each of specific points in human body pass through a meridian line (Zhang et al., 2010). Recent studies from Schlaeger et al. (2017) and Rahimi et al. (2018) showed that acupuncture could reduce pain and anxiety in the labor process. There are many acupressure points in human body, and every point has different effect in the body. Acupressure could also increase the production of endorphin hormones which function as a painkiller. To reduce pain, there are several acupressure points that could be pressed. One of them is the LI 4 (Hegu) point (Gönenç \& Terzioğlu, 2020).

Non-pharmacological therapy to relieve pain may also be administered through distraction techniques, one of which is listening to Quranic verses. This therapy stimulates delta brainwave which makes the listener feel comfort and tranquil (Wirakhmi et al., 2018). Quran recital therapy with correct rhythm and pronunciations will result in the decrease of anxiety level, Ghofar (2012) confirmed that $65 \%$ of therapy subjects felt a sense of tranquility and anxiety reduction, while Elzaky (2011) concluded that listening to Quranic recital of Surah Ar-Rahman transmits a soundwave which affects the movements of human cells; it is also activates pain pressure lanes and is succeeded by electrical stimulation of the substantia grisea cerebri in waking the analgesic neurotransmitter (endorphin, encephalin, dinorphin) which acts as pain suppressor. Surah Ar-Rahman is a chapter in the Quran believed to have medicinal properties if being listened to repeatedly with the correct recital (Wahida et al., 2015). Surah ArRahman also has repetitive verses which give

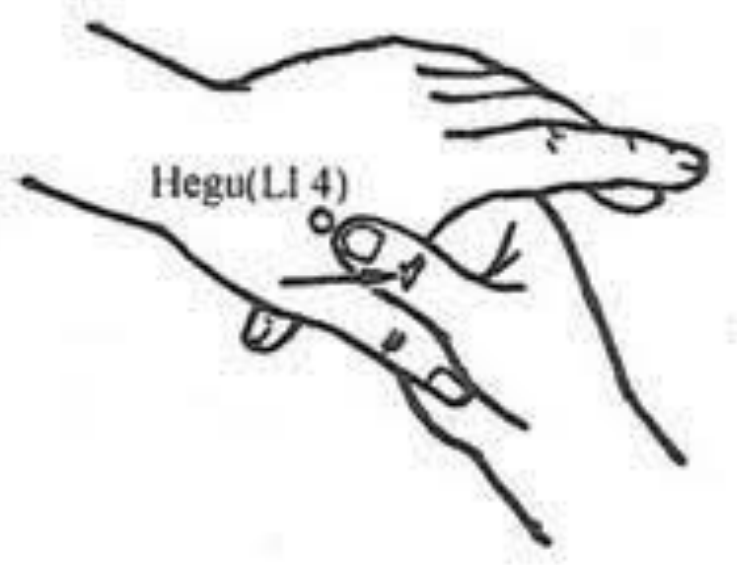

Figure 1. Hegu LI 4 Pressure Point

accentuated rhythm to the listeners. As repetitive verses can be appealing and behave as hypnosis, so patients brainwaves will attune into the rhythm and increase the production of serotonin and endorphin, which gives relaxing, serene, and delighting effects (Wahida et al., 2015).

Music may also be used to minimize labor pain, as music may give energy and subliminal commands through its rhythm; music with an appropriate tempo may help mothers to regulate their breathing in labor process. Classical music is commonly used to distract pain perception. Faradisi, (2012) proved that music could reduce anxiety, stress level, bad emotions and physical pain, and relax the muscles. Our study aims to assess the effectivity of Hegu LI 4 acupressure point with Quranic recital intervention of Surah Ar-Rahman in reducing labor pain intensity within the first stage active phase

\section{MATERIALS AND METHODS}

The study uses quasi experimental design with nonequivalent control group design, which means the subjects grouping was not random. In this design, we compare Hegu LI 4 acupressure group with Surah ArRahman Quranic recital group. 30 laboring mothers were treated with Hegu LI 4 acupressure within 10 minutes in the Hegu spot in the right/left hand, while the other 30 laboring mothers were treated with Quranic recital of Surah Ar-Rahman with MP3 device within 20 minutes. These two groups were compared with pretest, intervention, and posttest questionnaire.

Study population was the entirety of mothers within the first stage active phase labor process who fulfilled all inclusion criteria. The criteria were normal labor with gestational period $\geq 37$ weeks old, single gestation, head presentation, no labor induction, within first stage active phase (4-6 cm cervical opening), adequate his (uterine contractions $>3$ times in 10 minutes with contraction time $>40$ seconds), labor process supported with the husband or family, and not using pharmacological administration in reducing pain. Samples used are 30 
Table 1. Respondents' Demographics and Characteristics

\begin{tabular}{lccc}
\multicolumn{1}{c}{ Variables } & $\begin{array}{c}\text { Hegu LI 4 Acupressure } \\
\text { Mean } \pm \text { SD }\end{array}$ & $\begin{array}{c}\text { Quranic Recital of Surah } \\
\text { Ar-Rahman } \\
\text { Mean } \pm \text { SD }\end{array}$ & p \\
\hline Age & $26.73 \pm 4.386$ & $25.63 \pm 5.524$ & 0.156 \\
Parity & $1.60 \pm 0.675$ & $1.53 \pm 0.123$ & 0.804 \\
Anxiety & $11.50 \pm 5.557$ & $11.93 \pm 4.697$ & 0.251 \\
Pain score before intervention & $6.30 \pm 0.988$ & $6.33 \pm 0.988$ & 0.219 \\
\hline
\end{tabular}

Table 2. Intervention Effect to Labor Pain Level

\begin{tabular}{|c|c|c|c|c|c|c|}
\hline \multirow[b]{2}{*}{ Interventions } & \multicolumn{2}{|c|}{ Pain Level } & \multirow{2}{*}{$\begin{array}{l}\text { Pretest - } \\
\text { Posttest }\end{array}$} & \multirow[b]{2}{*}{ mean } & \multirow[b]{2}{*}{ 95\% C.I. } & \multirow[b]{2}{*}{$\mathbf{p}$} \\
\hline & $\begin{array}{c}\text { Pretest } \\
\text { Mean } \pm \text { SD }\end{array}$ & $\begin{array}{c}\text { Posttest } \\
\text { Mean } \pm \text { SD }\end{array}$ & & & & \\
\hline $\begin{array}{l}\text { Quranic Recital of } \\
\text { Surah Ar-Rahman }\end{array}$ & $6.33 \pm 1.184$ & $3.77 \pm 1.073$ & $2.57 \pm 1.006$ & \multirow[b]{2}{*}{-0.46} & \multirow[b]{2}{*}{$-0.919-(-0.015)$} & \multirow[b]{2}{*}{0.007} \\
\hline $\begin{array}{lll}\text { Hegu LI } & 4 \\
\text { Acupressure } & \end{array}$ & $6.30 \pm 0.988$ & $3.27 \pm 0.785$ & $3.03 \pm 0.718$ & & & \\
\hline
\end{tabular}

laboring mothers in each group, amounting to 60 samples.

Samples were gathered using non-probability sampling with consecutive sampling technique, meaning that samples were chosen through determining subjects who fulfilled the study criteria and treated within a set elapsed time until the number of subjects was enough.

Data were collected with direct observations on mothers who were within labors' first stage active phase; mothers were given pretests (preliminary observations) before proceeding with interventions of Hegu LI 4 acupressure in the first group and Quranic recital of Surah Ar-Rahman in the second group, followed by posttest (final observation). The intervention of Hegu LI 4 acupressure was done by the researchers, who had a level 4 acupressurist certificate of competency. Enumerators gave information to the researchers if there were laboring mothers who met the criteria and were willing to become study respondents. The intervention of the Quranic recital of Surah Ar-Rahman was done by enumerators with the recorded recital provided by the researchers. The administrations of Hegu LI 4 acupressure and Quranic recital were done after the mothers entered the delivery room, had cervical opening checked, and signed the informed consent. Each administration was carried out for 20 minutes. Both groups were given a Numeric Rating Scale (NRS) pain scale to assess the difference between the value of pretest and posttest. Data are presented within average standard deviation table and followed by normality test. Data are further analyzed with independent $\mathrm{T}$-Test for bivariate regression using significance rate $\alpha=0.05$.

\section{RESULTS}

Univariate analysis is used to analyze respondent characteristic distributions. Using 60 mothers as respondents divided in two groups, distribution characteristics can be seen in Table 1 .

From Table 1 we can stipulate that the comparability of subjects are homogenous and comparable. All variables in Table 1 do not have a significant difference ( $\mathrm{P}>0.05)$, implying that data are equitably distributed before the study progressed further.

According to Table 2 the average score of labor pain reduction in the Quranic recital group is $2.57 \pm$ 1.006, whereas the acupressure Hegu LI 4 group score is $3.03 \pm 0.718$. From the independent sample T-test, the resulting score is $0.919-(-0.015)$ with $\mathrm{P}<$ 0.007 under confidence interval of $95 \%$. To summarize, the decrease of labor pain score is greater in the Hegu LI 4 acupressure group, implying the effectiveness of acupressure statistically and clinically.

Figure 2 summarizes the comparison of labor pain intensity between intervention groups. Overall, two groups have a decreasing score in labor pain intensity from the pretest to posttest, but the Hegu LI 4 acupressure group has a greater decrease in labor pain than the Quranic recital of Surah Ar-Rahman group

\section{DISCUSSION}

Acupressure intervention in Hegu LI 4 could increase the level of endorphin hormones. Endorphin has an effect in pain relief (Hamidzadeh et al., 2012). Gate control theory explains that pain is transmitted by nerve fibers to the spinal cord before being transmitted to the brain. Synapses in the dorsal horn act as a closed gate to maintain impulses before reaching the brain. According to gate control theory, nerve fibers which have small diameters and carry pain stimuli from the nerves to the same gate could hinder the transmission of pain impulses through closing the gate (Kashanian \& Shahali, 2010).

Gate control theory also explains that, while labor is going on, pain impulses are transmitted from the uterus all along the large nerve fibers to the upper level of gelatinous substance in the spinal column and transmission cells project a pain message to the brain. The presence of stimuli renders the opposing message to become stronger and faster while transmitted in the gelatinous small nerve fibers, then 


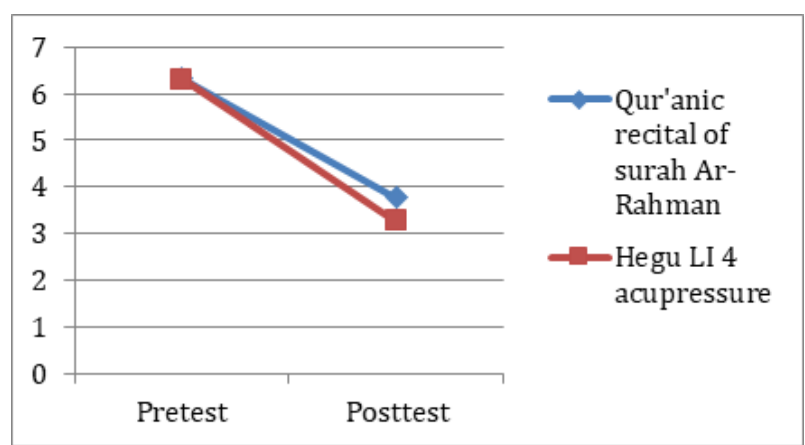

Figure 2. Comparison of Labor Pain Decrease

hindering the pain message so the brain does not process it (Koyyalamudi et al., 2016).

The administration of Hegu LI 4 acupressure is suspected to stimulate Ad fibers which inject into medulla spinalis. This process makes a segmental inhibition from pain stimuli which is inducted by $\mathrm{C}$ fiber in the other side of medulla spinalis. The resulting message will stimulate mechanoreceptors (Hamidzadeh et al., 2012). If the dominant impulses are induced from Delta A and C membranes, it will open said defenses which make mothers to perceive pain. But, if the pain is transmitted to the brain, the higher cortex center in the brain will modify pain perception (Schlaeger et al., 2017). Existing pressure in the Hegu LI 4 could help endorphin discharge in the body. Dabiri et al. (2014) also confirm that Hegu LI 4 acupressure could reduce the duration of labor's first stage.

Music can be utilized to minimize labor pain, as music gives energy and a message through the music's rhythm, so appropriate tempo can help mothers to regulate their breathing in labor. Commonly used music in pain distraction is classical music. Several studies prove that listening to music, especially classical music, can reduce the level of anxiety, stress, emotion, and physical pain. Music can be utilized as a pain reduction by countering stress and loosening flexed muscles as a reaction to the pain (Y.H. et al., 2010)

According to Wahida et al/ (2015), the application of Quranic recital of Surah Ar-Rahman as a therapy is proven effective in increasing the level of $\beta$ endorphin, which reduces pain intensity to laboring mothers; a recital with slow tempo with deep appreciation can induce a relaxing sensation. $\beta$ endorphin is a neuropeptide which consists of 31 amino acids produced by the hypophysis gland from the splitting of proopiomelanocortin (POMC) (Kovalitskaya \& Navolotskaya, 2011). Endorphin is produced naturally by the body and has the ability to inhibit pain transmission, so pain level is reduced (Fraser \& Cooper, 2009).

Another contributing factor is the belief of $\mathrm{Al}$ Quran as a holy book which contains God's commandments and life guidance for Muslims. Listening to Quranic recital can give someone a feel of being closer to God's presence, and unconsciously makes the listeners submit themselves to God, which boosts a relaxing feel, suppressing anxiety and increasing $\beta$-endorphin level as a pain suppressor (Faradisi, 2012).

Quranic recital which contain human voice harmonic melody is a good healing instrument, as listening to harmonic melody can induce a comforting feel and naturally increase the endorphin level, affecting the suppression of stress, fear, and anxiety hormones (Särkämö et al., 2014). As supported by this study, the therapy of Quranic recital of Surah ArRahman for 25 minutes can reduce the first stage active phase labor pain.

\section{CONCLUSION}

Hegu LI 4 acupressure and Quranic recital of Surah Ar-Rahman is proven to be used as a pain reductor in treating the first stage active phase labor pain. Acupressure group has a greater pain reduction level than Quranic recital group. The study result recommends that Hegu LI 4 acupressure can be utilized in addressing labor pain nonpharmacologically.

\section{REFERENCES}

Abdul Ghofar, L. N. (2012). he Influence Of Playing Therapy And Music Therapy (Listening Al-Qur'an : Juz Amma) To Anxiety Respond At Toddler.

Faradisi, F. (2012). Efektifitas Terapi Murotal dan Terapi Musik Klasik terhadap Penurunan Tingkat Kecemasan Pasien Pra Operasi di Pekalongan. Jurnal Psikologi Stikes Muhammadiyah Pekajangan Pekalongan. https://doi.org/10.1533/9780857096326.index

Fraser, D. M., \& Cooper, M. A. (2009). Buku ajar bidan myles. Jakarta: EGC.

Gönenç, I. M., \& Terzioğlu, F. (2020). Effects of Massage and Acupressure on Relieving Labor Pain, Reducing Labor Time, and Increasing Delivery Satisfaction. The Journal of Nursing Research: $\quad$ JNR. https://doi.org/10.1097/jnr.000000000000034 4

Hamidzadeh, A., Shahpourian, F., Orak, R. J., Montazeri, A. S., \& Khosravi, A. (2012). Effects of LI4 Acupressure on Labor Pain in the First Stage of Labor. Journal of Midwifery and Women's Health. https://doi.org/10.1111/j.15422011.2011.00138.x

Jones, L., Othman, M., Dowswell, T., Alfirevic, Z., Gates, S., Newburn, M., Jordan, S., Lavender, T., \& Neilson, J. P. (2012). Pain management for women in labour: an overview of systematic reviews. Cochrane Database of Systematic Reviews. https://doi.org/10.1002/14651858.cd009234.pu b2

Kashanian, M., \& Shahali, S. (2010). Effects of acupressure at the Sanyinjiao point (SP6) on the process of active phase of labor in nulliparas women. Journal of Maternal-Fetal and Neonatal Medicine. https://doi.org/10.3109/14767050903277662 
Kovalitskaya, Y. A., \& Navolotskaya, E. V. (2011). Nonopioid effect of $\beta$-endorphin. In Biochemistry (Moscow). https://doi.org/10.1134/S0006297911040018

Koyyalamudi, V., Sidhu, G., Cornett, E. M., Nguyen, V., Labrie-Brown, C., Fox, C. J., \& Kaye, A. D. (2016). New Labor Pain Treatment Options. In Current Pain and Headache Reports. https://doi.org/10.1007/s11916-016-0543-2

Larasati, T., \& Alatas, F. (2016). Dismenore Primer dan Faktor Risiko Dismenore Primer pada Remaja. Majority.

Rahimi, F., Goli, S., Soltani, N., Rezaei, H., \& Amouzeshi, Z. (2018). Effects of Complementary Therapies on Labor Pain: A Literature Review. Modern Care Journal. https://doi.org/10.5812/modernc.69306

Särkämö, T., Tervaniemi, M., Laitinen, S., Numminen, A., Kurki, M., Johnson, J. K., \& Rantanen, P. (2014). Cognitive, emotional, and social benefits of regular musical activities in early dementia: Randomized controlled study. Gerontologist. https://doi.org/10.1093/geront/gnt100

Schlaeger, J. M., Gabzdyl, E. M., Bussell, J. L., Takakura, N., Yajima, H., Takayama, M., \& Wilkie, D. J. (2017). Acupuncture and Acupressure in Labor. In Journal of Midwifery and Women's Health. https://doi.org/10.1111/jmwh.12545

Shahali, S., \& Kashanian, M. (2010). Effect of acupressure at the Sanyinjiao point (SP6) on the process of active phase of labor in nulliparas women. Journal of Babol University of Medical Sciences.

https://doi.org/10.1080/14767050903277662

Wahida, S., Andarini, S., \& Nooryanto, M. (2015). Al Qur ' an Surah Arrahman Recital Therapy Increase $\beta$-Endorphin Levels and Reduce Childbirth Pain Intensity on A. Journal Kedokteran Brawijaya.

Wirakhmi, I. N., Utami, T., \& Purnawan, I. (2018). Comparison of Listening Mozart Music With Murotal Al Quran on the Pain of Hypertension Patients. Jurnal Keperawatan Soedirman. https://doi.org/10.20884/1.jks.2018.13.3.813

Y.H., L., M.Y., C., \& H, C. C. (2010). Effects of music therapy on labour pain and anxiety in Taiwanese first-time mothers. Journal of Clinical Nursing.

Yazdkhasti, M., \& Pirak, A. (2016). The effect of aromatherapy with lavender essence on severity of labor pain and duration of labor in primiparous women. Complementary Therapies in Clinical Practice. https://doi.org/10.1016/j.ctcp.2016.08.008

Zhang, J., Troendle, J., Mikolajczyk, R., Sundaram, R., Beaver, J., \& Fraser, W. (2010). The natural history of the normal first stage of labor. Obstetrics and Gynecology. https://doi.org/10.1097/AOG.0b013e3181d559 25 